\title{
Cost-effectiveness of Early Use of Etanercept in the Treatment of Rheumatoid Arthritis
}

\author{
Graduate School of Clinical Pharmacy, Sookmyung Women's University, Seoul, Korea, \\ ${ }^{1}$ Department of Health Research, Korea Institute for Health and Social Affairs, Seoul, Korea, \\ ${ }^{2}$ Division of Rheumatology, Department of Internal Medicine, Hanyang University College of Medicine \\ and the Hospital for Rheumatic Diseases, Hanyang University, Seoul, Korea \\ Eui Kyung Lee, Ph. D., Sukja Ko M. S. ${ }^{1}$, \\ =국문초록= \\ Sang-Cheol Bae, M. D. ${ }^{2}$, Yoon-Kyoung Sung, M. D. ${ }^{2}$ \\ 이의경, 고숙자 ${ }^{1}$, 배상철 ${ }^{2}$, 성윤경 ${ }^{2}$ \\ 숙명여자대학교 임상약학대학원, 한국보건사회연구원 보건의료연구실 ${ }^{l}$, \\ 한양대학교 의과대학 내과학교실 류마티스내과, 한양대학교 류마티스병원
}

\section{류마티스관절염 치료에 있어 Etanercept의 조기사용전략에 대한 비용효과분석}

배경: 류마티스관절염의 치료전략으로는 항류마티스약제를 이용한 단계적 치료가 일반적이다. 최근에 개발 되어 류마티스관절염의 중요한 치료제로 자리매김한 종양괴사인자억제제는 관절염의 증상 감소 외에도 질 환의 진행을 억제하는데 매우 효과적인 것으로 알려져 있다. 이러한 우수한 효과로 인해 종양괴사인자억제 제의 조기사용의 필요성이 강조되고 있으나 높은 의약품비는 이를 초기치료약물로 사용하는데 있어 제한점 으로 지적되고 있다.

목적: 대표적인 종양괴사인자억제제인 etanercept (ETN)을 포함한 한국인 류마티스관절염 환자의 치료전략 에 있어서, ETN을 초기약물치료로서 사용하는 치료전략을 현재 일반적으로 시행되고 있는 타약제에 저항 성을 보일 경우에 $\mathrm{ETN}$ 을 사용하는 후기사용전략에 대한 비용-효과를 판단하고자 하였다

방법: 한국인 류마티스관절염 환자에서 MTX단독요법 후에 MTX와 leflunomide (LFN)병합요법에 저항성 을 보일 경우 ETN와methotrexate (MTX)병합요법을 사용하는 후기사용전략에 대하여 초기부터 ETM와 MTX를 사용하는 조기사용전략의 비용효과분석을 시행하였다. 단기간의 임상시험 결과들에 대해 Markov cohort simulation을 시행하였으며, 6개월간의 Health Assessment Questionnaire disability score의 경향을 1,000 명에 대해 5년간의 변화를 시뮬레이션하였으며, 이를 성과지표로서 질보정수명 (quality-adjusted life year: QALY)으로 환산하였다. 의약품 및 검사비와 같은 직접의료비용은 한국의 국민건강보험수가를 기준 으로 하여 계산하였다.

결과: 5년간의 시뮬레이션에서 $\mathrm{ETN}$ 의 조기사용전략에 있어서 후기사용전략에 대한 점증적 비용효과비 (Incremental cost-effectiveness ratio: ICER)는 1QALY당 78,101 (천원)로 계산되었다. 이를 10년, 15년, 30년 으로 연장한 감도분석에서 ICER는 1QALY당 30,012(천원), 6,620(천원), $-10,054$ (천원)로 계산되었다.

결론: 5년을 기준으로 하여 한국인 류마티스관절염 환자에 있어 ETN의 조기사용전략은 현재의 일반적인 후기사용전략에 비해 비용효과비가 좋다고 할 수는 없는 것으로 나타났다. 그러나, 간접비용을 포함하거나 장기간의 사용이 필요할 경우에는 $\mathrm{ETN}$ 의 조기사용전략의 비용효과비가 개선될 수 있을 것으로 판단된다.

Key words: Cost-benefit analysis, Arthritis, Rheumatoid, Quality-adjusted life years.

This study was supported by a grant of the Korea Healthcare technology R\&D Project, Ministry for Health, Welfare and Family Affairs, Republic of Korea (A084794).

Correspondence and request for reprints should be addressed to: Yoon-Kyoung Sung MD, PhD, Division of Rheumatology, Department of Internal Medicine, Hanyang University College of Medicine, Seoul"@133-792, korea; Tel.: +82.2-2290-9207Fax: +82.2-2298-8231; Email: sungyk@hanyang.ac.kr

접수일자: 09. 05. 29 심사일자: 09. 06. 01 게재일자: 09. 06. 11 


\section{INTRODUCTION}

Rheumatoid arthritis (RA) is a chronic illness of unknown etiology characterized by symmetric, erosive joint inflammation throughout the body ${ }^{1}$. Treatment involves nonsteroidal anti-inflammatory drugs, glucocorticoids, and disease-modifying antirheumatic drugs (DMARDs) $)^{2}$. The extent of joint erosion in early disease has resulted in the early initiation of DMARDs being a mainstay of the management of patients with $\mathrm{RA}^{3-5)}$ with methotrexate (MTX) being the gold standard. However, remission is uncommon with these treatments and the long-term outcomes can be poor, with many patients switching medication due to lack of efficacy or adverse effects. Consequently, a sequential treatment strategy involving DMARDs that varies with disease progression is a common intervention.

Recently, the introduction of new DMARDs such as leflunomide (LEF) and tumor necrosis factor (TNF) antagonists (infliximab, etanercept [ETN], and adalimumab) has transformed the management of $\mathrm{RA}^{6-9)}$.In particular, TNF antagonists have emerged as important therapies for RA because of their ability to reduce the signs and symptoms of disease, slow the rate of radiographic progression, and improve functional capacity. ETN was approved for use in Korea in 2003. The potential greater efficacy of ETN is associated with a much higher drug cost, making this a natural candidate for costeffectiveness analysis, and several studies have provided evidence of its costeffectiveness in patients with active RA who were resistant to traditional DMARDs therapy $^{10,11)}$.

Whilst clinical guidelines currently recommend the use of ETN as a step therapy after a nonresponse to traditional DMARDs $^{2}$, in early and established RA the combined use of ETN and MTX (the most widely used DMARD) is known to be more effective than monotherapy with either MTX or ETN alone $^{9,12)}$. Moreover, there have been several reports that the induction of remission with early use of ETN+MTX regimen significantly improves functional status and quality of life $(\mathrm{QoL})^{13-15)}$. These observations implicate for the optimal use of expensive biologic therapy, and hence another economic analysis is required for the new treatment strategy.

Therefore, in this study we compared the long-term cost-effectiveness of a sequential treatment strategy involving the early use of ETN with that for the conventional late use of ETN in Korean RA patients.

\section{MATERIALS AND METHODS}

\section{Model Framework}

The model compared two hypothetical treatment sequences based on the societal perspective. The first sequence was the 


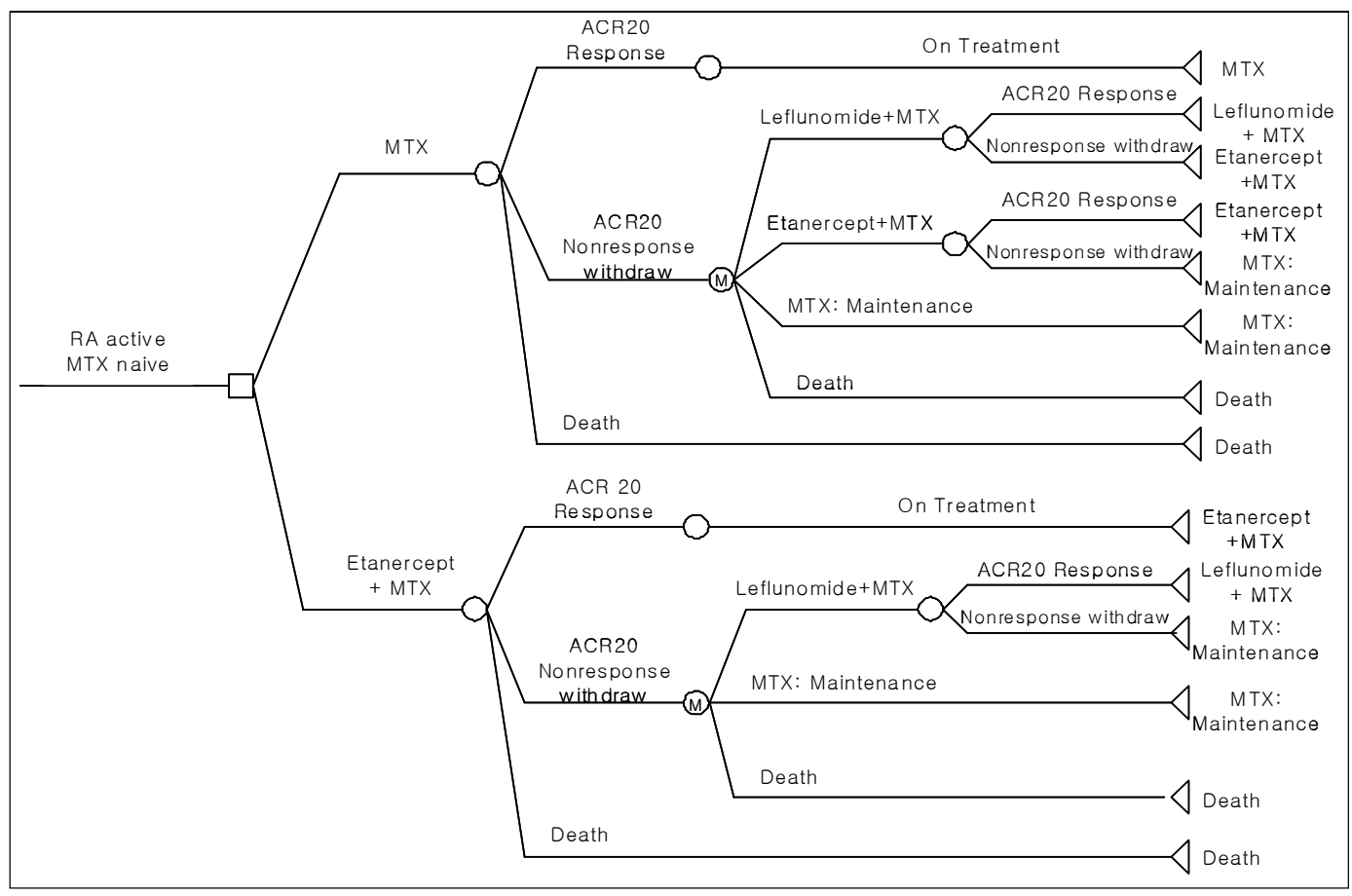

Figure 1. Decision Tree of clinical pathways for rheumatoid arthritis treatment. MTX, methotrexate.

conventional late use of ETN, in which the patients who failed MTX were treated with LEF+MTX followed by ETN+MTX for unresponsive cases, with the treatment finishing with MTX as a maintenance therapy. The second sequence was of early use, in which patients started directly on combination therapy of ETNand MTX. Discussion with clinical experts in Korea confirmed that these sequences were reasonable.

The decision tree of the clinical pathways for RA treatment is shown in Figure 1. Decision analysis and Markov cohort simulation were used based on a previously published model $^{10,16)}$. Outcomes were quantified as the quality-adjusted life years (QALYs). The model focused on the progression of the Health Assessment Questionnaire (HAQ) disability score, which ranges from 0 (best function) to 3 (worse function). The $6^{-}$ monthly trends in HAQ score over time were simulated for 1000 patients using Microsoft Excel, and the regression of HAQ/EuroQol (EQ-5D) utility yielded the gain in QALYs.

The model cycle was 6 months. After the first 6-month cycle, a patient could be either an initial responder and remain on treatment, or a nonresponder and be switched to the next treatment in the sequence. The mean HAQ improvement for responders was quantified using published data ${ }^{10,17)}$. Initial responders remained on treatment for multiple 
Table 1. Parameter values used in model estimation

\begin{tabular}{|c|c|c|c|c|c|}
\hline \multirow[b]{2}{*}{ Variable } & \multicolumn{2}{|c|}{$\overline{\mathrm{ETN}+\mathrm{MTX}}$} & \multicolumn{2}{|c|}{ MTX } & \multirow{2}{*}{$\begin{array}{c}\text { LEF+MTX } \\
\text { [Ref.] }\end{array}$} \\
\hline & $\begin{array}{c}\text { Early use } \\
\text { [Ref.] } \\
\end{array}$ & $\begin{array}{l}\text { Late use } \\
\text { [Ref.] }\end{array}$ & $\begin{array}{l}\text { Early use } \\
\text { [Ref.] }\end{array}$ & $\begin{array}{l}\text { Late use } \\
\text { [Ref.] }\end{array}$ & \\
\hline Effectiveness variable & & & & & \\
\hline Response (ACR20) at 6 months (\%) & $\begin{array}{c}82 \\
{[18]}\end{array}$ & $\begin{array}{l}71 \\
{[9]}\end{array}$ & $\begin{array}{c}64 \\
{[18,29]}\end{array}$ & $\begin{array}{l}24 \\
{[8,9,39]}\end{array}$ & $\begin{array}{c}46 \\
{[40]}\end{array}$ \\
\hline $\begin{array}{l}\text { Withdrawals at each } 6 \text {-month period } \\
(\%)\end{array}$ & $\begin{array}{c}6.5 \\
{[18]}\end{array}$ & $\begin{array}{l}3.4 \\
{[9]}\end{array}$ & $\begin{array}{c}10.4 \\
{[18,29]}\end{array}$ & $\begin{array}{c}14.7 \\
{[8,9,39]}\end{array}$ & $\begin{array}{l}19.2 \\
{[40]}\end{array}$ \\
\hline $\begin{array}{l}\text { Initial HAQ improvement from } \\
\text { baseline }\end{array}$ & $\begin{array}{l}-1.0 \\
{[18]}\end{array}$ & $\begin{array}{l}-0.7 \\
{[9]}\end{array}$ & $\begin{array}{c}-0.45 \\
{[1829]}\end{array}$ & $\begin{array}{c}-0.22 \\
{[8,9,39]}\end{array}$ & $\begin{array}{l}-0.4 \\
{[40]}\end{array}$ \\
\hline $\begin{array}{l}\mathrm{HAQ} \text { improvement of } \mathrm{ACR} 20 \\
\text { responders at } 6 \text { months }\end{array}$ & $\begin{array}{c}-1.11 \\
{[10,17]}\end{array}$ & $\begin{array}{c}-0.83 \\
{[10,17]}\end{array}$ & $\begin{array}{c}-0.58 \\
{[10,17]}\end{array}$ & $\begin{array}{c}-0.38 \\
{[10,17]}\end{array}$ & $\begin{array}{c}-0.57 \\
{[10,17]}\end{array}$ \\
\hline $\begin{array}{l}\text { 6-monthly HAQ progression of } \\
\text { ACR20 responders }\end{array}$ & $\begin{array}{c}0.0051 \\
{[41]}\end{array}$ & $\begin{array}{c}0.0051 \\
{[41]}\end{array}$ & $\begin{array}{l}0.017 \\
{[41]}\end{array}$ & $\begin{array}{l}0.017 \\
{[41]}\end{array}$ & $\begin{array}{l}0.017 \\
{[41]}\end{array}$ \\
\hline $\begin{array}{l}\text { 6-monthly HAQ progression of } \\
\text { ACR20 nonresponders }\end{array}$ & $\begin{array}{l}0.065 \\
{[42]}\end{array}$ & $\begin{array}{l}0.065 \\
{[42]}\end{array}$ & $\begin{array}{l}0.065 \\
{[42]}\end{array}$ & $\begin{array}{l}0.065 \\
{[42]}\end{array}$ & $\begin{array}{l}0.065 \\
{[42]}\end{array}$ \\
\hline$\nabla$ Cost variable & & & & & \\
\hline $\begin{array}{l}\text { Drug costs at each } 6 \text {-month period } \\
\text { (thousand won) }\end{array}$ & 7,467 & 7,467 & 1,020 & 1,020 & 1,504 \\
\hline Monitoring costs at 6 (thousand won) & 191 & 191 & 190 & 190 & 225 \\
\hline $\begin{array}{l}\text { 6-monthly monitoring costs from } \\
\text { second period (thousand won) }\end{array}$ & 87 & 87 & 87 & 87 & 87 \\
\hline $\begin{array}{l}\text { Prescription and injection costs at } \\
\text { each 6-month period (thousand won) }\end{array}$ & 46 & 46 & 45 & 45 & 45 \\
\hline
\end{tabular}

HAQ, Health Assessment Questionnaire; ACR20, American College of Rheumatology-20.

6-month cycles until subsequent long-term withdrawal owing to lack of efficacy or an adverse event. At the point of long-term withdrawal, the patient was assumed to exhibit a worsening HAQ score and was switched to the next treatment in the sequence. The modeling time horizon for the base case was 5 years, and the death of patient was considered to be the termination of treatment.

The population in this model was assumed to comprise adult patients who had active
RA, a mean age of 50 years, and a baseline HAQ score of 1.7 based on a published ETN trial $^{18)}$. As disease duration significantly affects the response to treatment, the patient characteristics from similar studies were compared. A systematic MEDLINE literature search from 1996 to 2005 identified Englishlanguage articles concerning the drugs used in the two sequences. The parameter values for the modeling were extracted, and a meta-analysis was performed. 


\section{Modeling the Long-term Response to Treatment}

Since switching to the next treatment was triggered by a lack of response or withdrawal, American College of Rheumatology20 (ACR20) data and the withdrawal rates that were extracted from the finally selected clinicalliterature were used as transition probabilities.

Table 1 lists the initial improvements in HAQ scores for the ACR20 responders. In cases where only the mean HAQ changes for both ACR20 responders and nonresponders were published, the HAQ score for ACR20 responders were estimated based on the formula ofBrennan et $\mathrm{al}^{10)}$.

Subsequent long-term withdrawal occurred due to failure of treatment effect or adverse events. In cases where the ongoing drug therapy was withdrawn,it was assumed that the HAQ score increased again to the level of the first HAQ improvement after the administration of the corresponding drug.

Since one of the clinical pathways was death, the probability of death was included. Considering that the mortality risk is higher for patients diagnosed with RA than for a normal population, a relative risk (RR) for mortality of 1.32 was applied ${ }^{19)}$, and adjusted to the mortality of a normal population cohort obtained from the data of the Korea National Statistical Office.

The model assumed a slight long-term progression of disability over time even when patients were responding to treatment based on Brennan et al. ${ }^{10)}$. Regarding the $\mathrm{HAQ}$ progression level of ACR20 responders per cycle, the estimated value of 0.0051 was used for ETN+MTX, whereas 0.017 was used for MTX and MTX+LEF treatments as the long-term response to therapy. For the ACR20 nonresponders, the 6-month HAQ progression level of all drug therapy groups was estimated to be 0.065 .

Regarding the calculation of QALY from HAQ, we assumed that HAQ was linearly related to EuroQol (EQ-5D) in accordance with previous studies ${ }^{20-22)}$. In our study, the HAQ score was converted into QALYs based on the formula of Brennan et al. ${ }^{10)}$ : utility change $=0.86-0.20$ (HAQ score change) .

\section{Costs of Treatment Strategies}

The cost of RA treatment included drug and monitoring costs, and was calculated by multiplying the health insurance payment with the frequency of drug administration and the frequency of monitoring (Table 1). The frequencies of drug administration and monitoring were calculated based on existing clinical practices in Korea as obtained by consulting rheumatologists and from the ACR guideline $^{2)}$.

Data on direct costs such as drug purchases and injection and dispensing fees were obtained from the pharmaceutical 
Table 2. Indirect costs for 6 months by HAQ score (unit: thousand won)

\begin{tabular}{cccccc}
\hline \multirow{2}{*}{ State } & \multirow{2}{*}{ HAQ score } & Work capacity & \multicolumn{3}{c}{ Indirect costs by age groups (years)* } \\
& & & $50-54$ & $55-60$ & Above 60 \\
\hline \hline 1 & $<0.5$ & $0.5000[23]$ & 8,214 & 7,402 & 5,706 \\
2 & $0.5<1.1$ & $0.3770[23]$ & 10,235 & 9,223 & 7,109 \\
3 & $1.1<1.6$ & $0.2345[23]$ & 12,576 & 11,332 & 8,735 \\
4 & $1.6<2.1$ & $0.0547[23]$ & 15,530 & 13,994 & 10,787 \\
5 & $2.1<2.6$ & $0.0476[23]$ & 15,646 & 14,099 & 10,868 \\
6 & $>2.6$ & $0.0000[23]$ & 16,428 & 14,804 & 11,411 \\
\hline
\end{tabular}

- Data source: 2008 Statistics Survey Report on Wage Structure, Ministry of Labor [24].

benefits pricing file, health insurance fees of the Health Insurance Review Agency, and the National Health Insurance Statistics Yearbook. Monitoring costs included physician visits and test costs. During the initial 6after drug administration, monitoring was performed at $0,2,8,16$, and 24 weeks. However, from the second cycle the monitoring interval was every 2.

For the purpose of sensitivity analysis the costs of lost productivity were also calculated based on the severity of RA disease, which was categorized into six stages according to the HAQ score. The costs of lost productivity were estimated based on work capacity. We applied the research results of Kobelt et al. ${ }^{23)}$, who calculated work capacity according to the HAQ score: scores of 1.0, 0.5, and 0.0 were assigned to full-time employment, parttime employment, and unemployment, respectively.

The monthly labor costs and the annual special payments from the 2008 Statistics Survey Report on Wage Structure ${ }^{24)}$ were used as the data source for the monthly average incomes of laborers. The costs of lost productivity were calculated by multiplying the 6-monthly income by work capacity (Table 2). Also, it was considered that participation in financial activity occurred up to an age of 65 years on average, with retirement thereafter. Thus, the indirect costs were included only up to the age of 65

\section{Analyses}

Both strategies were simulated for 1000 patients using Excel. Estimated population mean costs and QALYs were calculated, and the incremental cost-effectiveness ratio (ICER) was determined from the mean differences in costs and QALYs. According to Korean guidelines for pharmacoeconomic evaluation $^{25)}$, this article took societal 
— E. K. Lee et. al.: Cost-effectiveness of early use of etanercept -

Table 3. Modeling results of 5 -year base case

\begin{tabular}{lccccc}
\hline $\begin{array}{l}\text { Sequence } \\
\text { number }\end{array}$ & $\begin{array}{l}\text { Effectiveness } \\
\text { (QALYs) }\end{array}$ & $\begin{array}{l}\text { Cost } \\
\text { (thousand } \\
\text { won) }\end{array}$ & $\begin{array}{l}\text { Incremental } \\
\text { QALY } \\
\text { (QALYs) }\end{array}$ & $\begin{array}{l}\text { Incremental } \\
\text { Cost } \\
\text { (thousand won) }\end{array}$ & $\begin{array}{l}\text { ICER } \\
\text { (thousand } \\
\text { won/QALY) }\end{array}$ \\
\hline $\begin{array}{l}\text { 1. Conventional late } \\
\text { use of ETN }\end{array}$ & 2.72 & 26,501 & - & - & - \\
\begin{tabular}{l} 
2. Early use of ETN \\
\hline
\end{tabular} & 3.06 & 53,380 & 0.34 & 26,878 & 78,101 \\
\hline
\end{tabular}

QALYs, quality-adjusted life years; ICER, incremental cost-effectiveness ratio.

perspective, and a 5\% discount rate was applied to both costs and QALYs.

The sensitivity analysis was performed to major parameters to consider the inherent uncertainty of the economic evaluation model of RA treatment. The following five key parameters were analyzed: (i) the effect of alternative scenarios on HAQ/QALY conversion based on the literature ${ }^{20-22)}$, (ii) mortality estimation, (iii) discount rate (3\% and 7.5\%), (iv) indirect costs, and (v) model time horizon (10, 15, and 30 years). Regarding indirect costs, as it is no clear if the indirect preference-based measures adequately capture utility losses due to decreased levels of income and productivity, indirect costs need be reported separately ${ }^{26)}$.

\section{RESULTS}

\section{Base case analysis}

The direct costs were estimated to be 26,879 thousand won higher in the second sequence (early use of ETN) than in the first sequence (late use of ETN). The second sequence was also estimated as providing an extra 0.34 QALYs over a 5-year time horizon. The incremental cost per QALY gained for the second sequence was 78,101 thousand won(Table 3).

\section{Sensitivity analyse}

Table 4 indicates that for the majority of parameters varied, the cost per QALY gained was above 20,000 thousand won, which is the implicit threshold for reimbursement in Korea. The sensitivity analysis of the coefficient representing the linear relationship between HAQ and QALY revealed that ICERs ranged from 47,768 thousand won per QALY to 92,977 thousand won per QALY gained.

Estimating the mortality of RA patients in Korea is difficult due to a lack of data. We therefore also used the estimates of mortality of the normal population (i.e., without allowing for the RR for RA patients) in the literature, which only changed the ICER by 82 thousand won per QALY, from 78,101 thousand won per QALY to 78,019 thousand 
won per QALY.

Korean pharmacoeconomic guidelinesuggests that sensitivity analyses should be conducted for discount rates of 3\% and 7.5\%. Changing the discount rates had little impact on the ICER: it was 76,232 thousand won per QALY and 80,412 thousand won per QALY for discount rates of $3 \%$ and $7.5 \%$, respectively.

The estimated cost per QALY gained can be improved by including the indirect costs of lost productivityand extending the model time horizon. The inclusion of indirect costs decreased the ICER from 78,101 thousand won per QALY to 36,568 thousand won per QALY. Also extending the time horizon from 5 years to 10, 15, and 30 years resulted in estimated costs per QALY gained of 30,012 thousand won, 6,620 thousand won, and $-10,054$ thousand won, respectively.

\section{DISCUSSION}

The aim of this study was to elucidate the cost-effectiveness of a sequential treatment strategy with early use of ETN comparing with the conventional late use of ETN in RA patients in Korea. Our study shows that the ICER for the strategy involving the early use of ETN with MTX relative to the strategy involving the late use of ETN was 78,101 thousand won per QALY gained. Willingnessto-pay (WTP) can be changed with the differences on the economic level of the nation, disease severity, burden of disease,

Table 4. Results of sensitivity analyses

\begin{tabular}{lcc}
\hline Parameter change & $\begin{array}{c}\text { Cost per QALY } \\
(1,000 \text { won/QALY })\end{array}$ & $\begin{array}{l}\text { Change from base case } \\
(1,000 \text { won/QALY })\end{array}$ \\
\hline \hline Base case & 78,101 & - \\
HAQ/QALY conversion & & $-30,333$ \\
$0.862-(0.327 \mathrm{HAQ})$ & 47,768 & $+14,877$ \\
$0.77-(0.168 \mathrm{HAQ})$ & 92,977 & $-10,187$ \\
$0.85-(0.23 \mathrm{HAQ})$ & 67,914 & $-11,462$ \\
$0.8285-(0.2344 \mathrm{HAQ})$ & 66,639 & -82 \\
Mortality & & \\
Normal-population mortality & 78,019 & $-1,869$ \\
Discount rate & & $+2,311$ \\
$3 \%$ & 76,232 & $-41,533$ \\
$7.5 \%$ & 80,412 & $-48,089$ \\
Cost & & $-71,481$ \\
Including indirect costs & 36,568 & $-88,155$ \\
Time horizon & & \\
10 years & 30,012 & \\
15 years & 6,620 & \\
30 years (lifetime) & $-10,054$ & \\
\hline
\end{tabular}


and budget impact of the alternatives. Although no definitive willingness-to-pay threshold has been established in Korea, it undoubtedly exceeds those in the UK $(£ 20,000-£ 40,000 / \mathrm{QALY})^{27)}$ and US $(\$ 50,000 /$ QALY ${ }^{28)}$. This implies that adopting a sequential treatment strategy with the early use of ETN in RAmay not be a costeffective alternative to the conventional treatment strategy in Korea. However, our ICER reduced from 78,101 thousand won to 30,012 thousand won and 6,620 thousand won per QALY gained when the treatment period was extended from 5 years to 10 and 15 years, respectively. Moreover, on a lifetime analysis, the early use of ETN was dominant compared with the late use of ETN, and hence the former strategy can be more cost-effective in the long term. In the US, 6-month to 3-year analyses seem to be preferred by managed care and health maintenance organizations while National Institute for Clinical Excellence (NICE), in the UK, assessment of TNF antagonists, a lifetime approach was requested. Although we understand that the benefits of modifying the course of the disease by early aggressive treatment will be evident only in the long term, we used a time horizon of 5 years in base case analysis because extrapolating to 5 years based on clinical trials may be too uncertain to be clinically acceptable.

Treating RA involves not one therapeutic agent but rather a sequence of therapies that are applied over a long time period. Thus, modeling therapeutic sequences is of particularimportance to long-term economic evaluations of DMARDs ${ }^{29}$. We chose the therapeutic sequence strategies based on the expert opinions of rheumatologists, because there has been no nationwide survey of RA treatment in Korea. In Korea, ETN is reimbursed by national health insurance when it is prescribed to patients with moderate to severe RA who have failed to respond to at least two DMARDs for 6(longer than 3each), one of which is MTX. Accordingly, doctors have been persuaded to implement step-up therapy from MTX to ETN+MTX in the clinical setting. On the other hand, many recent reports have suggested the advantage of starting ETN early in $\mathrm{RA}^{13-15)}$. Thus, our treatment sequences were modeled to examine the cost-effectiveness of a new potential sequential treatment strategy compared to the strategy currently employed in most clinical settings.

The choice of sequence used in this study was also constrained by technical considerations imposed by the Markov modeling assumptions, and the limited availability of information in the literature. For example, the combination of MTX and hydroxychloroquine (HCQ) is more frequently used than MTX monotherapy as either a first line or maintenance therapy, but the combination therapy could not be modeled because there is no report on ACR20 response rates for this 
treatment strategy. There has been a randomized controlled trial of a combination therapy with MTX, sulfasalazine, and HCQ for MTX-naïve patients ${ }^{30)}$, but we could not include this triple therapy in the sequence of step therapies for MTX-resistant patients.

Our analysis is likely to be conservative because we did not consider the savings in indirect costs from the early use of ETN in the base case analysis. The indirect costs from disability associated with RA are substantial $^{31)}$, including an increasing unemployment rate with increasing disease duration $^{32,33)}$, and decreased productivity ${ }^{34)}$. In our sensitivity analysis that included the indirect costs, the ICER unsurprisingly reduced from 78,101 thousand won to 36,568 thousand won per QALY gained.

This study was subject to several limitations. Its main limitations relate to data availability. The relative efficacy estimates were generated from separate controlled trials, which may not have been directly comparable. That is, most of the parameters in our model, such as the ACR20 achievement rate, the background HAQ score change, improvements in $\mathrm{HAQ}$ scores with therapy, and the equation used to calculate the utility from the HAQ score change were derived from clinical trials and economic studies conducted in Western countries ${ }^{10,11,35)}$. Our analytic model was based on the Trial of Etanercept and Methotrexate with Radiographic and Patients Outcomes ${ }^{18)}$ because only one open-label study for ETN and few well-designed cohort studies for RA patients have been reported in Korea ${ }^{36)}$.

Secondly, we were unable to include any costs for adverse drug reactions in the analyses. Often it is unclear whether events are directly related to the treatment, and frequently no data are available on the clinical management of such events. This issue is particularly difficult for small samples of patients with severe and sometimes long-standing disease, and the results of the analysis could be heavily influenced by comorbidity in the sample. Tuberculosis has been observed in patients receiving $\mathrm{TNF}^{-}$ blocking agents. In this regard physicians should monitor patients receiving etanercept for signs and symptoms of active tuberculosis, including patients who tested negative for latent tuberculosis infection. Patients who develop an infection should be evaluated for appropriate antimicrobial treatment. Both the monitoring and treatment cost need to be added as the cost for adverse drug reaction. However, in this study, we assumed that the frequency of severe adverse events did not differ between the sequential treatment strategies, due to all the treatment options in our sequences including both MTX and etanercept.

Thirdly, many clinical trials have shown that the progression of radiographic scores varies with the regimen. However, radiographic score change wasnot incorporated as 
a separate measure into our model owing to a lack of adequate data sets. We therefore conservatively assumed that the effect is included in the HAQ scores while patients are receiving treatment. Background $\mathrm{HAQ}$ scores and their percentage reductions were taken from Brennan et al. ${ }^{10)}$, and they may not accurately represent how the treatment effects of these drugs progress, especially in Koreans. Moreover, we used data sets of established RA in this analysis, and future studies should be performed based on the data of aggressive treatment with biological agents in early-RA patients. The clinical benefits of lower physical impairment will increase when any future benefit from radiographic stabilization of structural joint damage due to ETN and MTX is included, especially in early-RA patients. Thus, this is likely to increase the actual cost-effectiveness of a new strategy.

\section{CONCLUSIONS}

Our study suggests that the strategy of using combined ETN and MTX as an early treatment in RA should not be considered a cost-effective alternative to the conventional late use of ETN over a time horizon of 5 years. However, scenario analyses showed that the inclusion of indirect costs and long-term use might improve the costeffectiveness outcomes for the early use of ETN.

\section{ABSTRACT}

Objective: To compare the long-term cost-effectiveness of a sequential treatment strategy involving the early use of etanercept (ETN) with that for the conventional late use of ETN in Korean RA patients

Methods: A cost-effectiveness analysis was performed to compare two treatment sequences using etanercept with methotrexate: early versus late start to the rheumatoid arthritis (RA) patients in Korea. Decision analysis and Markov cohort simulation were used to extrapolate short-term clinical trial results to a long-term time horizon. The outcome was quantified as the qualityadjusted life years (QALYs). The 6-monthly trends in Health Assessment Questionnaire disability scores were simulated for 1,000 patients for 5and converted into QALYs. Direct medical costs including drugs and monitoring were estimated based on the Korean National Health Insurance reimbursement schedule.

Results: The incremental cost-effectiveness ratio for the early versus late use strategy was 78,101 thousand won per QALY gained, but this reduced to 30,012 thousand won, 6,620 thousand won, and - 10,054 per QALY gained when the treatment period was changed to 10, 15, and 30years, respectively.

Conclusions: These results show that a sequential treatment strategy with early use of ETN in RA may not represent a 
cost-effective alternative to the conventional late use of ETN over a 5-year time horizon. However, scenario analyses showed that both the inclusion of indirect costs and long-term use might further improve the costeffectiveness outcomes for the early use of ETN.

Key words: cost-benefit analysis, arthritis, rheumatoid, quality-adjusted life years.

\section{REFERENCES}

1. Harris ED, Jr. Rheumatoid arthritis. Pathophysiology and implications for therapy. $N$ Engl J Med 1990;322:1277-89.

2. Guidelines for the management of rheumatoid arthritis: 2002 Update. Arthritis Rheum 2002;46:328-46.

3. Finckh A, Liang MH, van Herckenrode CM, de PP. Long-term impact of early treatment on radiographic progression in rheumatoid arthritis: A meta-analysis. Arthritis Rheum 2006;55:864-72.

4. Fries JF. Current treatment paradigms in rheumatoid arthritis. Rheumatology (Oxford) 2000;39 Suppl 1:30-5.

5. Lard LR, Visser H, Speyer I, et al. Early versus delayed treatment in patients with recent-onset rheumatoid arthritis: comparison of two cohorts who received different treatment strategies. Am J Med 2001;111 :446-51.

6. Strand V, Cohen S, Schiff M, et al. Treatment of active rheumatoid arthritis with leflunomide compared with placebo and methotrexate. Leflunomide Rheumatoid Arthritis Investigators Group. Arch Intern Med 1999; 159:2542-50.

7. Maini R, St Clair EW, Breedveld F, et al.
Infliximab (chimeric anti-tumour necrosis factor alpha monoclonal antibody) versus placebo in rheumatoid arthritis patients receiving concomitant methotrexate: a randomised phase III trial. ATTRACT Study Group. Lancet 1999;354:1932-9.

8. Weinblatt ME, Keystone EC, Furst DE, et al. Adalimumab, a fully human anti-tumor necrosis factor alpha monoclonal antibody, for the treatment of rheumatoid arthritis in patients taking concomitant methotrexate: the ARMADA trial. Arthritis Rheum 2003; 48:35-45.

9. Weinblatt ME, Kremer JM, Bankhurst $\mathrm{AD}$, et al. A trial of etanercept, a recombinant tumor necrosis factor receptor: Fc fusion protein, in patients with rheumatoid arthritis receiving methotrexate. $N$ Engl $J$ Med 1999;340:253-9.

10. Brennan A, Bansback N, Reynolds A, Conway P. Modelling the cost-effectiveness of etanercept in adults with rheumatoid arthritis in the UK. Rheumatology (Oxford) 2004:43:62-72.

11. Kobelt G, Lindgren P, Singh A, Klareskog L. Cost effectiveness of etanercept (Enbrel) in combination with methotrexate in the treatment of active rheumatoid arthritis based on the TEMPO trial. Ann Rheum Dis 2005;64:1174-9.

12. Kremer JM, Weinblatt ME, Bankhurst AD, et al. Etanercept added to background methotrexate therapy in patients with rheumatoid arthritis: continued observations. Arthritis Rheum 2003;48:1493-9.

13. Bathon JM, Martin RW, Fleischmann RM, et al. A comparison of etanercept and methotrexate in patients with early rheumatoid arthritis. N Engl J Med 2000;343:1586-93.

14. Genovese MC, Bathon JM, Martin RW, et al. Etanercept versus methotrexate in patients with early rheumatoid arthritis: two-year 
radiographic and clinical outcomes. Arthritis Rheum 2002;46:1443-50.

15. Genovese MC, Bathon JM, Fleischmann RM, et al. Longterm safety, efficacy, and radiographic outcome with etanercept treatment in patients with early rheumatoid arthritis. $J$ Rheumatol 2005;32:1232-42.

16. Brennan A, Akehurst R. Modelling in health economic evaluation. What is its place? What is its value? Pharmacoeconomics 2000; 17:445-59.

17. Moreland LW, Schiff MH, Baumgartner SW, et al. Etanercept therapy in rheumatoid arthritis. A randomized, controlled trial. Ann Intern Med 1999;130:478-86.

18. Klareskog L, van der $\mathrm{HD}$, de Jager JP, et al. Therapeutic effect of the combination of etanercept and methotrexate compared with each treatment alone in patients with rheumatoid arthritis: double-blind randomised controlled trial. Lancet 2004;363:675-81.

19. Yelin E, Trupin L, Wong B, Rush S. The impact of functional status and change in functional status on mortality over 18 years among persons with rheumatoid arthritis. J Rheumatol 2002;29:1851-7.

20. Barton P, Jobanputra P, Wilson J, Bryan S, Burls A. The use of modelling to evaluatenew drugs for patients with a chronic condition: the case of antibodies against tumour necrosis factor in rheumatoid arthritis. Health Technol Assess 2004;8:1-91.

21. Hawthorne G, Buchbinder R, and Defina J. Functional Status and Health-related Quality of Life Assessment in Patients with Rheumatoid Arthritis. Centre for Health Program Evaluation, Monash University. 2000. Working Paper 116. (www.buseco.monasheduau/centres/ che.pubs/wp116.pdf)

22. Hurst NP, Kind P, Ruta D, Hunter M, Stubbings A. Measuring health-related quality of life in rheumatoid arthritis: validity, respon- siveness and reliability of EuroQol (EQ-5D). Br J Rheumatol 1997; 36:551-9.

23. Kobelt G, Eberhardt K, Jonsson L, Jonsson B. Economic consequences of the progression of rheumatoid arthritis in Sweden. Arthritis Rheum 1999;42:347-56.

24. 2008 Statistics survey report on wage structure. Ministry of Labor 2005.

25. Bae EY, Choi SE, Kim JH. Guidelines for economic evaluation in pharmaceutical benefits system. Health Insurance Review Agency 2005. (http://www.hira.or.kr/cms/rg/rgb/ pds_14/1185707_4617.html)

26. Maetzel A, Tugwell P, Boers M, et al. Economic evaluation of programs or interventions in the management of rheumatoid arthritis: defining a consensus-based reference case. I Rheumatol 2003;30:891-6.

27. Guide to the methods of technology appraisal. National Institute for Clinical Excellence. 2004. (www.nice.org.uk)

28. Kaplan RM, Bush JW. Health-related qulity of life measurement for evaluation research and policy analysis. Health Psychol 1982;1: 61-80.

29. O'Dell JR, Haire C, Erikson N, et al. Efficacy of triple DMARD therapy in patients with $R A$ with suboptimal response to methotrexate. J Rheumatol 1996;23 Suppl 44:72-4.

30. Callahan LF. The burden of rheumatoid arthritis: facts and figures. I Rheumatol 1998;25 Suppl 53:8-12.

31. van Jaarsveld CH, Jacobs JW, Schrijvers AJ, et al. Effects of rheumatoid arthritis on employment and social participation during the first years of disease in The Netherlands. Br J Rheumatol 1998;37:848-53.

32. Jantti J, Aho K, Kaarela K, Kautiainen H. Work disability in an inception cohort of patients with seropositive rheumatoid arthritis: a 20 year study. Rheumatolog.(Oxford) 1999; 38:1138-41. 
33. Zink A, Braun J, Listing J, Wollenhaupt J. Disability and handicap in rheumatoid arthritis and ankylosing spondylitis-results from the German rheumatological database. German Collaborative Arthritis Centers. J Rheumatol 2000;27:613-22.

34. Yelin E, Trupin L, Katz P, et al. Association between etanercept use and employment outcomes among patients with rheumatoid arthritis. Arthritis Rheum 2003;48:3046-54.

35. Kobelt G, Jonsson L, Lindgren P, Young A, Eberhardt K. Modeling the progression of rheumatoid arthritis: a two-country model to estimate costs and consequences of rheumatoid arthritis. Arthritis Rheum 2002;46: 2310-9.

36. Choi BR, Joung CI, Lee HS, Uhm WS, Kim TH, Jun JB, Yoo DH, Bae SC. The efficacy and safety of etanercept in patients with active rheumatoid arthritis receiving methotrexate. Korean J Med 2004;66:513-20.

37. Kobelt G, Eberhardt K, Geborek P. TNF inhibitors in the treatment of rheumatoid arthritis in clinical practice: costs and outcomes in a follow up study of patients with RA treated with etanercept or infliximab in southern Sweden. Ann Rheum Dis 2004;63:4-10.

38. Strand V, Tugwell P, Bombardier C, Maetzel A, Crawford B, Dorrier C, Thompson A, Wells G. Function and health-related quality of life: results from a randomized controlled trial of leflunomide versus methotrexate or placebo in patients with active rheumatoid arthritis. Leflunomide Rheumatoid Arthritis Investigators Group. Arthritis Rheum 1999;42:1870-8.

39. Keystone EC, Kavanaugh AF, Sharp JT, et al. Radiographic, clinical, and functional outcomes of treatment with adalimumab (a human anti-tumor necrosis factor monoclonal antibody) in patients with active rheumatoid arthritis receiving concomitant methotrexate therapy: a randomized, placebo-controlled, 52-week trial. Arthritis Rheum 2004;50: 1400-11.

40. Kremer JM, Genovese MC, Cannon GW, et al. Concomitant leflunomide therapy in patients with active rheumatoid arthritis despite stable doses of methotrexate. A randomized, double-blind, placebo-controlled trial. Ann Intern Med 2002;137:726-33.

41. Scott DL, Pugner K, Kaarela K, et al. The links between joint damage and disability in rheumatoid arthritis. Rheumatology (Oxford) 2000:39:122-32.

42. Young A, Dixey J, Cox N, et al. How does functional disability in early rheumatoid arthritis (RA) affect patients and their lives? Results of 5 years of follow-up in 732 patients from the Early RA Study (ERAS). Rheumatology (Oxford) 2000;39:603-11. 